\title{
LUTSK KARAITE MANUSCRIPTS AND DOCUMENTS IN THE JÓZEF SULIMOWICZ COLLECTION
}

\author{
ANNA SULIMOWICZ \\ Department of Turkish Studies and Peoples of Inner Asia \\ Faculty of Oriental Studies, University of Warsaw \\ Krakowskie Przedmieście 26/28, 00-928 Warszawa, Poland \\ e-mail: anna.sulimowicz@uw.edu.pl
}

Józef Sulimowicz (1913-1973), a Polish Karaite, Turkologist and passionate bibliophile, collected a large number of Karaite manuscripts, books and documents in his lifetime. His collection, which includes items originating from both western communities and Crimea, is the only one of its kind in Poland. However, neither an inventory list, nor a catalogue have ever been assembled for the collection. Therefore, its exact content has remained largely unknown. The present paper discusses archival materials of the Karaite community in Lutsk stored in the Sulimowicz collection. It also looks at their origin, status and their research value.

Key words: Karaites, Polish Karaites, Karaite community in Lutsk, Karaim language, Karaite manuscripts, Józef Sulimowicz.

Unlike in Lithuania, Russia and Ukraine, the vast majority of Karaite manuscripts and printed books in Poland has remained in the hands of members of the Karaite community. Aleksander Dubiński estimated that there were altogether approximately two hundred such items (Dubiński 1979, p. 150). An attempt to compile a catalogue of Karaim manuscripts in Poland was made by A. Dubiński and J. Sulimowicz in the 1960s (Dubiński 1985, p. 24). Regrettably, this undertaking has never been completed. In 2012 Michal Németh (Jagiellonian University) in collaboration with Mariola Abkowicz (Adam Mickiewicz University in Poznań) and Anna Sulimowicz (University of Warsaw) launched a new project aimed at assembling data on all available Karaim manuscripts in private hands in Poland and compiling a comprehensive catalogue of them all. The largest such collection was gathered by Józef Sulimowicz, a Karaite from Halicz.

${ }^{1}$ Project financed by the Polish National Science Centre (Narodowe Centrum Nauki), grant number DEC-2011/03/D/HS2/00618. 
Born on December 25th 1913 Józef Sulimowicz was the second son of Leon Szulimowicz, ${ }^{2}$ an engine driver, and Helena née Ickowicz. His father on the distaff side was a grandnephew of ribbi Jeshua-Josef Mordkowicz, hazzan in Halicz in 18661884 and a tireless scribe who copied countless prayer books and translated the Pentateuch and other books of the Bible into Karaim and replicated them in several handwritten copies. In 1933, after graduating from the State Gymnasium No. 2 in Stanisławów (nowadays Ivano-Frankivsk), Józef Sulimowicz enrolled at the newly opened Institute of Oriental Studies at the University of Warsaw. He was among the first students of the Turkology Seminar initiated by Professor Ananiasz Zajączkowski in the autumn of 1933. He also attended lectures at the Eastern Institute, a government-supported academic institution promoting Promethean ideas, where he became a member of the Orientalist Youth Circle (Maj 2007, pp. 65, 123). Granted a scholarship by the Eastern Institute in 1936, he spent a few months in Istanbul and Dobrudja. In the autumn of 1939 he was due to defend his Master's Degree thesis on a translation of the Pentateuch published in Gozlev in 1841 and to obtain employment in the Karaim Museum founded in Troki by Seraya Shapshal, a leader of the Karaim community, for his collection of caraimica and orientalia. The outbreak of World War II regrettably put an end to all these plans. In 1941, just like many young men in eastern Poland occupied by the Soviet Union, Józef Sulimowicz was conscripted into the Red Army. It was only in 1944 that he was finally permitted to join the Polish Army in the USSR. He fought in the ranks of the 4th Jan Kiliński Infantry Division at the battle of Kolberg in March 1945. He remained in the military after the war. Promoted to captain in 1945 and then to major, colonel lieutenant and finally colonel, he served as chief of the Officers' Club in Warsaw in the "cultural section" of the Polish Army. In 1960 he was appointed director of the Central Library of the Army, a position that perfectly suited his interest in old books and manuscripts.

As early as 1950 Sulimowicz made an attempt to return to the University of Warsaw and complete his degree in Turkology. However, he was refused permission by the military authorities. It was only in 1968 that, with the help of his former teacher, Professor Ananiasz Zajączkowski, he managed to resume his studies and in 1969 he was awarded his Master of Arts in Turkish philology after defending a thesis on lexical material from the Crimean Karaim linguistic monument of $1734 .^{3}$ Soon afterwards, however, he was diagnosed with bowel cancer. Decommissioned in 1972 , he died on 3rd March 1973.

Sulimowicz's research interests focused mainly on the cultural and linguistic heritage of the Polish and Crimean Karaims. Regrettably, the list of his publications is not long. "The little time he had for academic work in his chosen field, together with his serious illness and subsequent death prevented J. Sulimowicz from perpetuating his profound knowledge in academic publications" - A. Dubiński stated in Sulimowicz's obituary (Dubiński 1974, p. 365). Aside from a few notes, book reviews, entries on

${ }^{2}$ In 1939 the family name Szulimowicz was officially changed to Sulimowicz, but only after the war did Leon's sons begin to use the new surname.

${ }^{3}$ Sulimowicz, J.: Materiał leksykalny krymskokaraimskiego zabytku językowego (druk z 1734 r.), Part I: $R O$ 1972, Vol. 35, pp. 37-76; Part II: RO 1973, Vol. 36, pp. 47-104. 
oriental studies in The Encyclopedia of The Book and The Polish Bibliographical Dictionary, and his master's thesis mentioned above, he published just one article. ${ }^{4}$

It was during his studies in the 1930s that Józef Sulimowicz began to show interest in old books and manuscripts (Dubiński 1985, p. 20). He had first become acquainted with them in his early years, as there were numerous printed and handwritten old prayer books in the kienesa (Karaite prayer house) in Halicz and in many houses of Karaite families as well. His interests in this field were not limited solely to Karaim books. A committed bibliophile, he acquired Ottoman manuscripts (Majda 1967, p. 139) during a scholarship in Istanbul in 1936, and in the early 1950s while garrisoned in Wrocław (Breslau) he collected German publications on Oriental subjects, not infrequently rescuing them from destruction.

Józef Sulimowicz's efforts as a manuscript collector was inextricably linked to his interests in the Karaim language. He had already started to collect linguistic materials during his studies in the 1930s. At his request, in 1937 Józef Lobanos, a hazzan in Wilno (Vilnius) and Zarach Zarachowicz from Halicz compiled handwritten copies of translations of the Book of Proverbs into the north- and south-western dialects of the Karaim language. These two manuscripts may be regarded as the beginnings of Sulimowicz's own collection. The collector's interest was mainly focused on items written in Karaim, he also collected all available manuscripts, books and documents in Hebrew, Polish and Russian. Therefore, the collection consists of items very different from one another in terms of their type and origin. For obvious reasons the Halicz manuscripts constitute the majority of the collection, but a relatively large number of items originating from Lutsk are also included.

On 9th September 1944 the Soviet authorities and the Soviet controlled Polish Committee of National Liberation (Polski Komitet Wyzwolenia Narodowego) signed an agreement in Lublin regarding the resettlement of Poles from the Ukrainian and Belorussian SSR. According to its terms, Poles and Jews who were citizens of the Polish Republic before 17 September 1939 were allowed to resettle with their families in Poland. Although Karaims were not mentioned in the document, they were also granted the right to "repatriation", which in reality meant their forced expulsion. "Encouraged" by frequent visits of representatives of the State Repatriation Office, sixteen Lutsk Karaims decided to leave their hometown and resettle in the west in the "Recovered Territories" within the new borders of Poland (Dubińska 1999, p. 9). They settled in Opole in Upper Silesia. Among them was Józef Kaliski (1887-1986), a member of the community's board of administration before 1939. Since very few Karaims (scarcely about 10 individuals) remained in Lutsk Kaliski brought the community's archives to Poland.

When exactly the archive was transferred to Warsaw remains unknown. We learn from the collector's private notes ${ }^{5}$ that Sulimowicz visited Kaliski in 1962. On May 2nd he wrote: "This morning I came back from Opole, where I had spent 3

${ }^{4}$ Mistar i halicko-karaimskie surałar, published in Roczniki Biblioteczne 1968, Vol. 1, No. 4, pp. 37-49. Sulimowicz describes in it a special device used by Karaite scriveners in Halicz to mark lines on a blank sheet of paper.

${ }^{5}$ J. Sulimowicz's daily notes $1961-1962$ in the author's possession. 
days. Mr. Kaliski gave me or lent me many interesting tiny manuscripts, a few Karaite printed books published in Russia. (...) I looked through the Lutsk community's archives which have been so carefully preserved by Mr. Kaliski. There are many interesting documents, letters etc. Some of these were published by A. Mardkowicz in his article in Karaj Awazy". "When we compare this information with the Lutsk materials which are actually a part of Sulimowicz's collection, we see that three groups of documents originated from Lutsk: the official archives of the local Karaite community, old documents found by Aleksander Mardkowicz in the gallery for women in the Karaite prayer house in Lutsk prior to its renovation in the mid-1920s, and books and manuscripts from the Kaliski family archive.

As far as the official archives of the community are concerned, they contain a wide variety of documents which can be divided into several groups according to their content. The first group consists of a register recording births, deaths, and marriages from 1871 till 1947 in Russian and Polish. ${ }^{7}$ This group of documents also includes two census lists (revizskie skazki) from 1834 and $1858^{8}$ containing names, family relations and ages of the community's members. Among the documents that Mardkowicz found were a few belonging to this category, e.g. a list of Lutsk Karaites who died in 18531855 , compiled in 1874 by Simha Leonowicz, the hazzan in Lutsk at that time, ${ }^{9}$ a list of the community's members living in villages in the vicinity of Lutsk around $1846,{ }^{10}$ and a table containing a list of the names of Karaites and information on their properties and sources of livelihood compiled around 1854. ${ }^{11}$ Although all these documents are important mostly for the light they shed on the demography and genealogy of the Lutsk Karaites, they also provide us with valuable data on anthroponomastics.

Another group consists of financial records, such as the general ledgers for the years 1857 (in Russian) ${ }^{12}$ and for 1874 (in Hebrew), ${ }^{13}$ cash books for the years $1927-$ $1943,{ }^{14}$ tax registers for the years $1858^{15}$ and $1859^{16}$ as well as various documents

${ }^{6}$ Aleksander Mardkowicz (1875-1944), Karaim writer and activist from Lutsk, found old letters and other documents in the "babiniec", i.e. a gallery for women. He published some of these as an appendix to his article in Karaj Awazy (Mardkowicz 1933). For his edition of the letters see Németh (2009).

${ }^{7}$ Archive of the Lutsk Karaite Community, No. VII/17, 17a, 18, 18a, 19, 19a.

${ }^{8}$ Ревизская Сказка 1834 года Апреля дня [...] вольнской Губернии Уезднаго Казённаго Города Луичка о состоявших в отом Караимах Купиах и Мещанах (Archiwum Gminy Karaimskiej w Łucku, henceforth: AGKŁ/VII/14); Ревизская Сказка / Тысяча восемсоть пятьдесять восьмаго года мая восьмаго дня, Вольнской Губерній Города Луика о состоящихъ мужска и женска пола Мъъцанах Караимахъ (AGKŁ/VII/13). Both documents also contain data from previous censuses held respectively in the years 1816 and 1850.

${ }^{9}$ AGKL/VII/22/14.

${ }^{10}$ AGKL/VII/22/08.

${ }^{11}$ The document written in Hebrew, Karaim and Russian was given the provisional catalogue number 4/79. For its content see Sulimowicz (2014).

${ }^{12}$ AGKŁ/VII/12.

${ }^{13}$ AGKL/VII/15.

${ }^{14}$ AGKŁ/VII/9-11.

${ }^{15}$ AGKŁ/VII/24/13.

${ }^{16}$ AGKŁ/VII/24/12. 
referring among others to fund-raising efforts to support the renovation and maintenance of the prayer house. The content of a file called "Rachunki" (Invoices) ${ }^{17}$ containing the financial records of the community's expenditure in the inter-war period is also included in this category of documents.

The documents covering this period have been meticulously organised in seven files. Aside from those mentioned above they include the following: "Statuty" (Statutes, AGKŁ/VII/1) documenting the community's endeavours to draft the statute of the Karaim Religious Association in the Republic of Poland as well as the Law governing its status in the Republic, which was finally enacted in 1936, "Uchwały" (Resolutions, AGKL/VII/2), containing resolutions of the community's General Assembly and Administration Board, and "Wybory hachana" (Election of the hachan, AGKL/VII/3), which features documents detailing the election of Hadji Seraya Shapshal in 1927. The next two files refer to the cemetery and lands owned by the community ("Cmentarz", AGKŁ/VII $/ 6^{18}$ ) and to the prayer house ("Kienesa", AGKŁ/VII/4 ${ }^{19}$ ). The last file contains documents on various issues ("Sprawy różne", AGKŁ/VII/5).

As was mentioned above, in the mid-1920s Mardkowicz came across a large number of old documents in the gallery for women. In his article in Karaj Awazy he vividly described his "discovery" and published seven letters and two other documents, as well as an elegy kyna and an akidah (a text on the sacrifice of Isaac) he found there. However, the number of documents from the "babiniec" is much larger. Regrettably, they include no original catalogue or inventory list which could provide precise information on the provenance of these documents. Therefore, based on the remarks and notes that Mardkowicz made on some of them we can only surmise - albeit with a high degree of probability - that these may be the documents that Mardkowicz came across in the "babiniec". Among them are numerous documents in Polish, Russian, Hebrew and Karaim referring to the Lutsk Karaites in the 18th and 19th centuries. Only a few of them have been explored, and only in a very limited way. For instance, the so-called Summariusz, a list of documents concerning the Karaites issued between 1560-1792 and kept in the city and land archives. ${ }^{20}$ A. Zajączkowski, who was granted access to this document by Mardkowicz, cites some records from this batch in his outline of the history of Karaites in Volhynia (Zajączkowski 1933, pp. 24-32). Another document originating most probably from the "babiniec", namely a list of "proposals" (demands in fact) that the Karaims drew up and submitted to Count Gustaw Olizar who invited them to settle in his demesne in Korosteszów, ${ }^{21}$ was published most probably by Mardkowicz himself in Karaj Awazy (Z dziejów 1936, pp. 17-19). The fact remains, however, that the content of the overwhelming majority of

${ }^{17}$ AGKŁ/VII/7.

${ }^{18}$ For more on the content of this file, see Sulimowicz (2010).

${ }^{19}$ For more on the content of this file, see Sulimowicz (2008).

${ }^{20}$ Summarjusz różnych dokumentów tak do Miasta Łucka jako też do Omelaniczka i innych iakie się tylko w aktach Euckich Grodzkich i Ziemskich tyczace się Karaimów wynaleśdź mogły od Roku 1560 aż do Roku 1792 na żądanie tychże Karaimów Euckich wyszukanych, AGKŁ VII/24/15.

${ }^{21}$ AGKŁ/VII/24/05. 
these documents has remained unexplored up till now. However, they may shed much light on some lesser known or even unknown aspects of the community's life. Thus, to take one example, a file with the catalogue number AGKL/VII/23 includes numerous petitions to the Russian authorities referring to matters that in the 19th century seemed most troublesome to Lutsk Karaims: helping young Karaites avoid conscription into the army and establishing a new cemetery after the community's former cemetery had been expropriated. Another example is the above-mentioned manuscript No. 4(79) which provides us with data on the economic status of the community in the 19 th century.

The documents from the "babiniec" are valuable not only from the point of view of historical research, but also from a linguistic perspective. However, there are fewer documents written in Karaim than in Polish or Russian. Twenty-four letters make up a significant part of this group of manuscripts. Németh ${ }^{22}$ recently published a critical edition comprising twenty of them. Aside from letters from the 19th and 20th centuries there are also a few religious texts, for instance translations of hymns and prayers for Sukkot, Shavuot and other holidays, penitential poems and prayers (selichot and bakkeshot), a translation of the Book of Esther etc. ${ }^{23}$

In his diary Sulimowicz mentioned that Kaliski had shown him the community's archive as well as a number of "tiny" manuscripts. As there is neither an inventory list nor any notes on particular documents, it cannot be determined with absolute certainty which precisely of the numerous small manuscripts, consisting in many cases of just one or two leaves, were the ones that were presented and then transferred similarly to the community's archive in Warsaw to become a part of the collection. However one group of manuscripts stored together (file No. JSul.I.38) may originate from Lutsk, since judging from the penmanship and the kind of paper used we can presume that they were written there. Unlike the documents stored by Mardkowicz, the overwhelming majority of which are documents dealing with administrative and economic issues, these items concern exclusively religion and liturgy. All written in the southern dialect of Karaim, they include prayers, liturgical and paraliturgical hymns, as well as parts of translations of the Bible (the Book of Psalms, Proverbs of Salomon, the Book of Esther, the Song of Songs) and two kynas (lamentations for the dead) from the first half of the 19th century. Since the purpose of this paper is not to present a detailed analysis of the content of particular manuscripts, I have confined myself to this general description.

The Sulimowicz collection includes at least three handwritten books that originate from Lutsk, or at least there are certain grounds for supposing that they do. One of them, namely manuscript No. JSul.I.02, bears the name of Józef Kaliski and this demonstrates that the Karaim activist not only showed Sulimowicz a number of tiny manuscripts, but might have handed him over some larger items, too. The above-mentioned manuscript contains a rich collection of paraliturgical songs zěmīrōt in Hebrew

\footnotetext{
${ }^{22}$ See Németh (2010, 2011, 2012, 2013a, 2013b), cf. also Németh (2009).

${ }^{23}$ File No. AGKŁ/VII/22.
} 
and Karaim copied in 1807 by Mordekhay, the son of Joseph (Sultanski?) from Lutsk. The second document is a translation of the Book of Job (with verses in Hebrew followed by verses in Karaim). Written in 1814 by Yaaqov, the son of Ishak, who in turn can be identified as Yaaqov, the son of Ishak Gugel (1786 - after 1858), it was assigned the catalogue number J.Sul.I.03. Noteworthy is the fact that the south-western dialect of the Karaim language used in both of these manuscripts includes archaic features (e.g. the presence of front labials in certain positions). ${ }^{24}$

The third manuscript is No. JSul.I.11. It is a small $(165 \times 115 \mathrm{~mm})$ personal prayer book containing 132 handwritten leaves with a translation of the Book of Jeremiah and various penitential prayers $(k \bar{i} n \bar{o} t)$ in Hebrew and Karaim. According to a colophon on folio 132 recto, the manuscript was written in 5638 (i.e. in 1878/79). The scrivener is not mentioned by name. However, we find on folio 52 verso the names of a number of the owner's relatives noted together with their dates of death. Furthermore, folios 53 recto- 55 recto include zichrōnot, prayers for the souls of the dead, which include a list of deceased family members. Compared to the data from the census list of 1858 and civil records, these pieces allow us to identify the owner of the prayer book - and at the same time its scrivener - as Avraham, the son of IshakNisan Firkowicz (1846-1914), a Karaite from Lutsk and a sexton at the prayer house. Zachariasz Szpakowski (1901-1986) who had already left Lutsk for Warsaw in January 1944 (Urzeczeni 2013, p. 197) was Abraham's grandson. From this fact we can deduce that not only Kaliski, but also Szpakowski may have contributed to Sulimowicz's collection.

As the catalogue project is incomplete, there is still a possibility that more manuscripts and documents originating from Lutsk will be discovered in the future. However, it must be conceded that those catalogued up till now provide us with a wealth of data on various aspects of life in the Lutsk Karaite community in the 18th20th centuries, as well as on the south-western Karaim dialect.

As far as access to the Lutsk manuscripts and documents is concerned, it is worth mentioning that another project was launched in tandem with the catalogue project. In 2012 The Association of Polish Karaims obtained a grant from the Ministry of Culture and National Heritage enabling it to carry out conservation work on some of the most valuable manuscripts. The project, entitled "02261/13/FPK/NIMOZ Ratunkowe prace konserwatorsko-restauratorskie nad wybranymi karaimskimi rękopisami i starodrukami" (Urgent conservation and restoration work on selected Karaite manuscripts and old prints), continued in 2013 and 2014. Among the items covered by the project was the above-mentioned No. J.Sul.I.03 containing a translation of the Book of Job. The conservation work on it was successfully completed in 2013. All the restored manuscripts and old prints have been digitalised. The Association of Polish Karaims hopes to pursue this project further over the next few years, which in the future would ensure the restoration and digitalisation of all manuscripts thereby making them accessible.

\footnotetext{
${ }^{24}$ For historical phonology of south-western Karaim see Németh (2014).
} 


\section{References}

Dubińska, A. (1999): Garść danych o Karaimach z Łucka. Awazymyz Vol. 2, No. 3, pp. 9-10.

Dubiński, A. (1974): Józef Sulimowicz (1913-1973). Przegląd Orientalistyczny Vol. 4, No. 88, pp. $366-365$.

Dubiński, A. (1979): Karaimische Handschriften in polnischen Sammlungen. CAJ Vol. 23, Nos $3-$ 4, pp. $147-150$

Dubiński, A. (1985): Karaimskie rukopisi iz kollekcii Ju. Sulimoviča v Varšave. In: Abdurahmanov, G. A. - Hodžiev, A. P. et al. (eds): Tjurkskoe jazykoznanie. Materialy III. Vsesojuznoj tjurkologičeskoj naučnoj konferencii, Taškent 10-12.IX.1980, pp. 20-24.

Maj, I. P. (2007): Działalność Instytutu Wschodniego w Warszawie 1926-1939. Warsaw.

Majda, T. (1967): Katalog rękopisów tureckich i perskich. Warsaw (Katalog rękopisów orientalnych ze zbiorów polskich, Vol. 5, Part 2).

Mardkowicz, A. (1933): Sahyncyna "babinecnin”. Karaj Awazy No. 6, pp. 1-10.

Németh, M. (2009): Errors with and without Purpose: A. Mardkowicz's Transcription of Łuck-Karaim Letters in Hebrew Script. Studia Linguistica Universitatis Iagiellonicae Cracoviensis Vol. 128, pp. 69-101.

Németh, M. (2010): North-western and Eastern Karaim Features in a Manuscript Found in Luck. In: Mańczak-Wohlfeld, E. - Podolak, B. (eds): Studies on the Turkic World. A Festschrift for Professor St. Stachowski on the Occasion of His 80th Birthday. Kraków, pp. 75-94.

Németh, M. (2011): Unknown Lutsk Karaim Letters in Hebrew Script (19th-20th Century). A Critical Edition. Kraków (Studia Turcologica Cracoviensia 12).

Németh, M. (2012): A North-western Karaim Manuscript Found in Lutsk - A Case of Dialect Mingling? Studia Linguistica Universitatis Iagiellonicae Cracoviensis Vol. 129, pp. 139-162.

Németh, M. (2013a): Karaim Letters of Jehoszafat Kapłanowski. I. A Critical Edition. Studia Linguistica Universitatis Iagiellonicae Cracoviensis Vol. 130, pp. 237-257.

Németh, M. (2013b): Karaim Letters of Jehoszafat Kapłanowski. II. Linguistic Analysis. Studia Linguistica Universitatis Iagiellonicae Cracoviensis Vol. 130, pp. 259-276.

Németh, M. (2014): A Historical Phonology of Western Karaim. Alevolars and Front Labials in the South-western Dialect. Studia Linguistica Universitatis Iagiellonicae Cracoviensis Vol. 131, pp. $247-267$.

Sulimowicz, A. (2008): Kenesa karaimska w Łucku w świetle dokumentów z archiwum gminy. In: Bairašauskaite, T. - Kobeckaitè, H. (eds): Orientas Lietuvos Didžiosios Kunigaikatijos visuomenes tradicijoje: Tototriai ir Karaimai / Orient in the Social Tradition of the Grand Duchy of Lithuania: Tatars and Karaims / Orient $w$ tradycji spoteczeństwa Wielkiego Księstwa Litewskiego: Tatarzy i Karaimi. Vilnius, pp. 273-281.

Sulimowicz, A. (2010): Z dziejów gminy karaimskiej w Łucku. Gminny „dom dochodowy“. In: Siemieniec-Gołaś, E.-Georgiewa-Okoń, J. (eds): Od Anatolii po Syberię. Świat turecki w oczach badaczy. Kraków, pp. 143-149.

Sulimowicz, A. (2014): A Document on the Economic Status of the Lutsk Karaites in the Mid-19th Century. Karaite Archives No. 2, pp. 1-21.

Urzeczeni $(2013)=$ Urzeczeni Orientem. Listy Ananiasza Zajaczkowskiego do Tadeusza Kowalskiego 1925-1948. Warszawa.

Zajączkowski, A. (1933): Karaimi na Wołyniu. Osobne odbicie z Rocznika Wołyńskiego. Vol. III, Równe.

Z dziejów (1936) = Z dziejów rozwoju gminy karaimskiej w Łucku. Karaj Awazy Vol. 10, pp. $16-19$. 